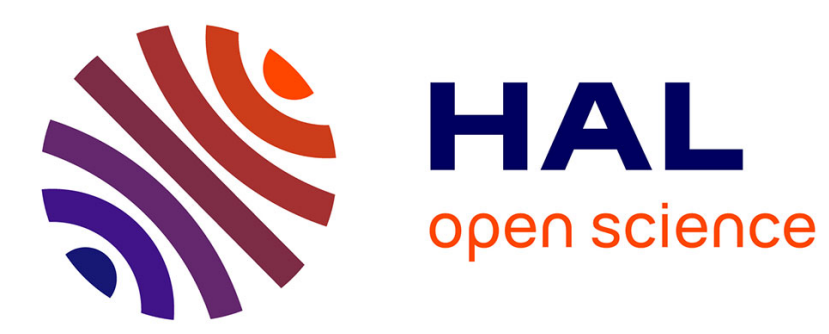

\title{
Solventless Synthesis of N-Protected Amino Acids in a Ball Mill
}

Laure Konnert, Anne Gauliard, Frédéric Lamaty, Jean Martinez, Evelina

Colacino

\section{To cite this version:}

Laure Konnert, Anne Gauliard, Frédéric Lamaty, Jean Martinez, Evelina Colacino. Solventless Synthesis of N-Protected Amino Acids in a Ball Mill. ACS Sustainable Chemistry \& Engineering, 2013, 1 (9), pp.1186-1191. 10.1021/sc4001115 . hal-00940108

\section{HAL Id: hal-00940108 \\ https://hal.science/hal-00940108}

Submitted on 9 Feb 2021

HAL is a multi-disciplinary open access archive for the deposit and dissemination of scientific research documents, whether they are published or not. The documents may come from teaching and research institutions in France or abroad, or from public or private research centers.
L'archive ouverte pluridisciplinaire HAL, est destinée au dépôt et à la diffusion de documents scientifiques de niveau recherche, publiés ou non, émanant des établissements d'enseignement et de recherche français ou étrangers, des laboratoires publics ou privés. 


\title{
Solventless Synthesis of $\mathbf{N}$-Protected Amino Acids in a Ball Mill
}

\author{
Laure Konnert, Anne Gauliard, Frédéric Lamaty, Jean Martinez, and Evelina Colacino* \\ Institut des Biomolécules Max Mousseron (IBMM) UMR 5247 CNRS - UM I-UM II, Université Montpellier II, Place E. Bataillon, \\ 34095 Montpellier Cedex 5, France
}

ABSTRACT: An eco-friendly methodology for preparing carbamate $N$-protected $\alpha$-amino acids is described using ball-milling technology. Some $\beta$-amino acids were also investigated in this study. This solvent-free methodology gave Boc-, Z-, and Fmoc- $N$-protected compounds in good to excellent yields with improved environmental impact compared to classical syntheses in solution. Different planetary ball mills were employed. The results are also discussed according to the different process parameters (grinding material, number of balls, rotation speed).

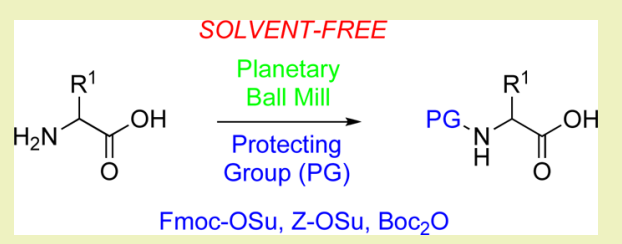

KEYWORDS: Amino Acids, Ball mill, Protective groups, Solvent free, E-factor

\section{INTRODUCTION}

For several years, the awareness of environmental problems caused by human activity has led scientists to change their way of "thinking chemistry", considering the 12 Green Chemistry Principles. ${ }^{1}$ As a result, new green and sustainable chemical processes have recently grown at a rapid pace, leading to the use of safer reagents or solvents, diminishing the generation of toxic and nontoxic waste through alternative synthetic methodologies and experimental techniques ${ }^{1-5}$ that limit energy consumption and solvent use. ${ }^{6}$ A strong emerging field of research is the employment of techniques such as mixing, grinding, or ball milling to carry out chemical reactions in the absence of solvent, ${ }^{7-10}$ considerably decreasing the E-factor ${ }^{11}$ of the organic reactions. We have recently described new strategies for amide bond formation under solvent-free conditions using ball-milling technology ${ }^{12}$ for the preparation of peptides ${ }^{13,14}$ or amino acid analogues. ${ }^{15,16}$ Usually, peptide syntheses (in solution or solid phase) are carried out from $C$ to $N$ direction by assembly of amino acids through a protection/ deprotection coupling strategy according to well-established procedures. ${ }^{17}$ One of the most significant issues in peptide chemistry is the temporary protection of the $\alpha$-amino function of amino acids ${ }^{18,19}$ to ensure better activation of the C-terminal carboxylic function and to prevent side reactions (polymerization of the amino acid or uncontrolled synthesis of peptides). Nevertheless, this kind of synthesis requires huge quantities of solvents (2000-5000 kg for a large peptide) and the use of expensive building blocks. Protecting groups such as 9fluorenylmethyloxycarbonyl (Fmoc), ${ }^{20}$ tert-butyloxycarbonyl (Boc), ${ }^{21,22}$ and benzyloxycarbonyl $(\mathrm{Z})^{23}$ groups are most commonly used to mask the amino group of $\alpha$-amino acids. However, the majority of current synthetic procedures require the use of excess of reagents, volatile toxic organic solvents (THF, benzene, dioxane, chloroform, etc.) in dry or aqueous biphasic conditions, and long reaction times. In this contest, exploring low cost eco-friendly methods for the ease and simple preparation of $\mathrm{N}$-protected amino acids by ball milling is a challenging task, especially to reduce reaction time and temperature and to simplify workup procedures. Mechanochemistry has been scarcely exploited for the derivatization of biological molecules and their analogues. The only data reported so far deals with the functionalization of nucleosides $^{24-27}$ or carbohydrates. ${ }^{25}$ We describe herein a new strategy for the direct preparation of Boc-, Z-, and Fmocprotected $\alpha$-amino acids under solid-state solvent-free conditions ${ }^{28}$ by using a planetary ball mill. It is worth noting that in the case of $\alpha$-amino acids, the selective $N$-protection was achieved in a one-pot/two-step procedure; the $\alpha$-carboxylic acid function was temporarily masked in situ to avoid dipeptide formation and at the same time to reduce the total number of steps and subsequent purification of the $C$-protected intermediate. We investigated different variables influencing the success of individual reactions that are not driven by the nature of reactants and additives. Technical and process parameters ${ }^{29}$ such as type of ball mill apparatus, rotation frequency (up to $750 \mathrm{rpm}$ ), milling time, material of balls and jars (stainless steel or tungsten carbide), size and number of milling balls (up to 80, with a diameter of $0.5 \mathrm{~mm}$ ), and mode of operation (continuous or cycled) were also explored in some cases.

\section{RESULTS AND DISCUSSION}

Synthesis of tert-Butyloxycarbonyl (Boc) N-Protected Amino Acids. Boc protection is classically achieved under Schotten-Baumann conditions ${ }^{22}$ (use of a biphasic system: organic solvent-aqueous basic conditions) starting from amino acids.

Recently, the solvent-free synthesis of Boc-nucleosides has been described for the protection of exocyclic amino function of nucleosides ${ }^{26}$ by grinding cytidine with $\mathrm{Boc}_{2} \mathrm{O}$ in a ball mill in the presence of DMAP as base. Solvent-free Boc-protection of primary and secondary amines has also been recently 
Scheme 1. General Scheme for N-Boc Protection of $L$-Phenylalanine

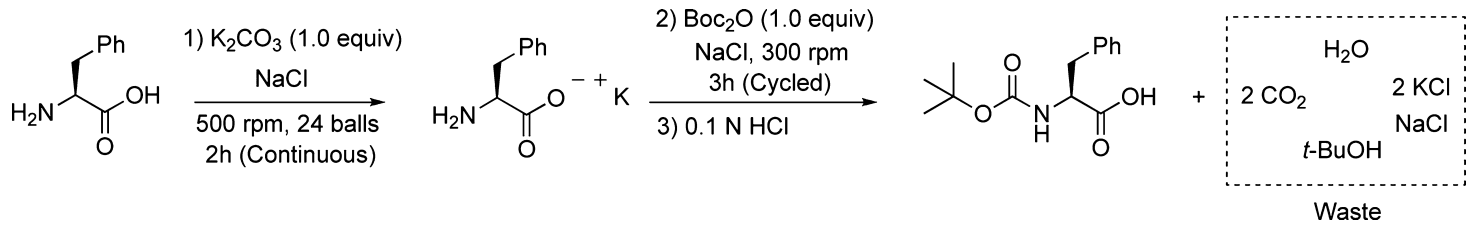

Table 1. tert-Butyloxycarbonyl N-Protected Amino Acids ${ }^{a, b}$

\begin{tabular}{|c|c|c|c|}
\hline & $\begin{array}{l}\text { 1) } \mathrm{K}_{2} \mathrm{CO}_{3} \text { (1.0 equiv) } \\
\underset{\mathrm{NaCl}}{\stackrel{\text { Planetary Mill }}{\longrightarrow}} \\
500 \text { rpm, } 24 \text { balls } \\
\text { 2h (Continuous) }\end{array}$ & $\begin{array}{l}\text { 2) } \mathrm{Boc}_{2} \mathrm{O} \text { (1.0 equiv) } \\
\mathrm{NaCl} \\
300 \mathrm{rpm} \text { 3h (Cycled) } \\
\text { 3) Acidic Work-up }\end{array}$ & \\
\hline entry & $\alpha$-amino acid & $N$-protected $\alpha$-amino acid & yield $(\%)^{c}$ \\
\hline 1 & H-Phe-OH & Boc-Phe-OH & 100 \\
\hline 2 & $\mathrm{H}-\mathrm{Tyr}(\mathrm{Me})-\mathrm{OH}$ & Boc- $\mathrm{Tyr}(\mathrm{Me})-\mathrm{OH}$ & 95 \\
\hline 3 & $\mathrm{H}-\mathrm{Ser}(\mathrm{Bzl})-\mathrm{OH}$ & Boc-Ser(Bzl)-OH & 96 \\
\hline 4 & $\mathrm{H}-\mathrm{Thr}(\mathrm{Bzl})-\mathrm{OH}$ & Boc-Thr(Bzl)-OH & 85 \\
\hline 5 & $\mathrm{H}-\mathrm{Glu}(\mathrm{Bzl})-\mathrm{OH}$ & $\mathrm{Boc}-\mathrm{Glu}(\mathrm{Bzl})-\mathrm{OH}$ & 68 \\
\hline 6 & $\mathrm{H}-\mathrm{His}(\mathrm{Bzl})-\mathrm{OH}$ & Boc-His(Bzl)-OH & 72 \\
\hline 7 & $\mathrm{H}-\mathrm{Trp}($ For $)-\mathrm{OH}$ & Boc-Trp(For)-OH & 95 \\
\hline 8 & $\mathrm{H}-\mathrm{Val}-\mathrm{OH}$ & Boc-Val-OH & 86 \\
\hline
\end{tabular}

${ }^{a}$ Configuration of all the substrates is $L .{ }^{b}$ General method using $12 \mathrm{~mL}$ stainless steel jar in a planetary ball mill: (step 1) $\alpha$-amino acid (0.605 $\mathrm{mmol}), \mathrm{K}_{2} \mathrm{CO}_{3}(0.605 \mathrm{mmol}), \mathrm{NaCl}$ (quantity in grams corresponding to the total weight of the reactants), 24 steel balls $(0.5 \mathrm{~mm}$ diameter) at 500 rpm for $2 \mathrm{~h}$; (step 2) $\mathrm{Boc}_{2} \mathrm{O}\left(0.605 \mathrm{mmol}\right.$ ) and $\mathrm{NaCl}$ (quantity in grams corresponding to the total weight of $\mathrm{Boc}_{2} \mathrm{O}$ introduced) at $300 \mathrm{rpm}$ (three cycles of $1 \mathrm{~h}, 10 \mathrm{~min}$ intervals between each cycle), inversed rotation. ${ }^{c}$ Isolated yield after liquid-liquid extraction.

performed via a carbonyldiimidazole (CDI)-mediated approach (grinding the reaction media with a spatula) ${ }^{30}$ in a two-step procedure in the presence of DMAP as well. However, only one step was performed without any solvent. $L$-Phenylalanine was selected as benchmark for a one-pot/two-step protocol involving the transient $\alpha$-carboxylic acid protection as the internal salt in the presence of an inorganic base (step 1), followed by the introduction of stoichiometric amounts of $\mathrm{Boc}_{2} \mathrm{O}$ (step 2); the optimized conditions are reported in Scheme 1 .

The reaction was performed in a planetary mill using a 12 $\mathrm{mL}$ stainless steel jar with 24 balls $(0.5 \mathrm{~mm}$ diameter). In our first attempts, a one-step protocol was used, milling the $\alpha$ amino acid directly with the base and the protecting group derivative at $500 \mathrm{rpm}$ for $2 \mathrm{~h}$ without any additive. Monitoring the reaction by reverse phase HPLC revealed very low conversion of the starting amino acid, probably due to inefficient mixing, resulting from the formation of a sticky paste inside the reactor. Therefore, we speculated that introduction of an inert additive that is able to keep the crude as a powder during the whole mixing process could be a solution. In the presence of molecular sieves $4 \AA$ or $\mathrm{MgSO}_{4}$ (inert to the reaction), the conversion remained low (20\%), and the recovery of the product after careful acidic workup was particularly difficult. In contrast, the crude resulted in a nice white powder when $\mathrm{NaCl}$ was used, and it was selected as the additive of choice for the next trials. At this point, we argued that catalytic amounts of free $\alpha$-carboxylic acid still present in the mixture during milling could probably be responsible for the poor results. For this reason, we envisaged that a temporary salt protection of the $C$-terminal was suitable, directing our tests toward the conception of a two-step protocol as shown in Scheme 1. For both steps, chemical parameters were investigated, such as different bases $(\mathrm{KOH}$, sodium, potassium, or cesium hydrogenocarbonates or carbonates, triethylamine, or DMAP), variable processes, presence or not of $\mathrm{NaCl}$ (added in each step in a corresponding amount equal to the total weight of the reactants), different rotation speeds (from 200 up to 500 $\mathrm{rpm}$ ), increasing number of balls (from 6 to 24), different reaction times ( $30 \mathrm{~min}$ up to $4 \mathrm{~h}$ for each step), and using continuous or cycled milling.

Because it was not possible to have direct evidence for the quantitative formation of the carboxylate after the first step, the efficiency of both steps was concomitantly optimized with an evaluation on the yield of the final protected amino acid. In addition, we observed that conversion and reaction time were affected by the $\mathrm{NaCl}$ quantity added in each step. For "highly diluted solid solutions", the conversion remained moderate, even after extended reaction times (more than $4 \mathrm{~h}$ ), while in "concentrated solid solutions", the mixing was poor and the crude was a paste with all the balls agglomerated around the chemicals. Reaction conditions needed to be also adjusted to promote a fast kinetic for $\mathrm{N}$-protection while diminishing the kinetic for $\mathrm{Boc}_{2} \mathrm{O}$ degradation. We observed that the tuning of the mechanical energy transferred to the mixture through different combinations of rotation speed/number of balls had an influence on the reaction kinetics. As a general trend, at high rotation speed (500 or $650 \mathrm{rpm}$ ) using 6,12 , or 24 stainless steel balls, $\mathrm{Boc}_{2} \mathrm{O}$ degradation remained significant, which translated again into lower conversion rates (around 40\%). The better results were finally obtained with a cycled milling mode for the second step (at $300 \mathrm{rpm}$ during three cycles of $1 \mathrm{~h}$ each, with $10 \mathrm{~min}$ pause in between), inverting the rotation in between two consecutive cycles, as shown in Scheme 1. The final product was recovered by liquid-liquid extraction from diethyl ether, after careful acidification of the crude with $10 \%$ 
Table 2. Benzyloxycarbonyl N-Protected Amino Acids ${ }^{a}$

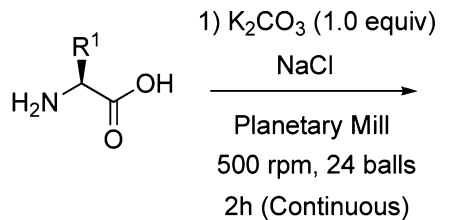

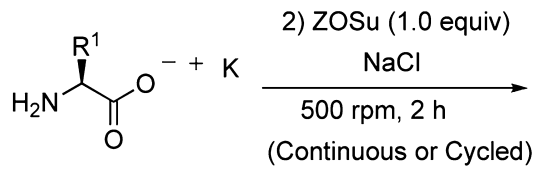

3) Acidic Work-up

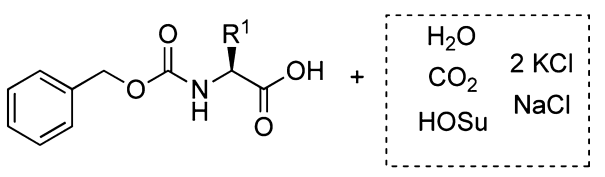

Pure

Waste

$\begin{array}{cc}N \text {-protected } \alpha \text {-amino } \text { acids }^{b} & \text { yield }(\%)^{c} \\ \text { Z-Phe-OH } & 75 \\ \text { Z-Tyr(Me)-OH } & 78 \\ \text { Z-Ser(Bzl)-OH } & 88 \\ \text { Z-Thr(Bzl)-OH } & 87 \\ \text { Z-Glu(OBzl)-OH } & \\ \text { Z-His(Bzl)-OH } & 95 \\ \text { Z-His(Trt)-OH } & 97 \\ \text { Z-Trp(For)-OH } & 100 \\ \text { Z-D-Lys(Z)-OH } & 73 \\ \text { Z-Val-OH } & 75 \\ \text { Z-Ala-OH } & 89 \\ \text { Z-D,L-3-Aib-OH }{ }^{e} & 85\end{array}$

${ }^{a}$ Configuration of all the substrates is $L$ except when differently stated. ${ }^{b} 12 \mathrm{~mL}$ stainless steel jar in a planetary ball mill: (step 1) $\alpha$-amino acid (0.605 $\mathrm{mmol}$ ), $\mathrm{K}_{2} \mathrm{CO}_{3}(0.605 \mathrm{mmol}), \mathrm{NaCl}$ (quantity in grams corresponding to the total weight of the reactants), 24 stainless steel balls $(0.5 \mathrm{~mm}$ diameter) at $500 \mathrm{rpm}$ for $2 \mathrm{~h}$; (step 2): $\mathrm{ZOSu}(0.605 \mathrm{mmol}$ ) and $\mathrm{NaCl}$ (quantity in grams corresponding to the total weight of ZOSu introduced) at $500 \mathrm{rpm}$ for $2 \mathrm{~h}$ (continuous milling). ${ }^{c}$ Isolated yield after workup. ${ }^{d}$ Continuous milling $500 \mathrm{rpm}$ for $2 \mathrm{~h}$ (twice). ${ }^{e}$ Cycled milling at $500 \mathrm{rpm}$ : 12 cycles of $10 \mathrm{~min}, 10 \mathrm{~min}$ intervals between each cycle, inversed rotation).

aqueous citric acid or $0.1 \mathrm{~N} \mathrm{HCl}$. The only byproducts obtained (Scheme 1) were removed in the aqueous phase (inorganic salts or eventually residual $\alpha$-amino acid) and by simple evaporation ( $t$-butanol or $\mathrm{CO}_{2}$ ), while the Boc- $N$ phenylalanine amino acid was recovered in quantitative yield as a white powder without any additional purification step (Table 1 , entry 1). The methodology was extended to other commercially available $\alpha$-amino acids; a selection of data is given in Table 1. Noteworthy, no diacylated products could be identified in the crude.

Synthesis of Benzyloxycarbonyl (Z) N-protected amino acids. The preparation of Z-protected amino acids is classically achieved by the addition of benzyl chloroformate $(\mathrm{Z}-\mathrm{Cl})$ to an alkaline solution of amino acid or ester ${ }^{23}$ or alternatively using a $\mathrm{N}$-hydroxysuccinimide ( $\mathrm{HOSu}$ ) derivative (ZOSu) or dibenzyldicarbonate $\left(\mathrm{Z}_{2} \mathrm{O}\right)$ in hazardous solvents such as THF or dioxane in dry conditions. Diverse Z-protected $\alpha$ - and $\beta$-amino acids were prepared using a planetary ball mill (one-pot/two-step protocol), investigating the reactivity of $\mathrm{Z}$ derivatives ( $\mathrm{ZCl}, \mathrm{ZOSu}$, and $\mathrm{Z}_{2} \mathrm{O}$ ) as shown in Table 2. On the basis of the previous screening for Boc-protected amino acids, the same one-pot/two-step procedure was envisaged for the present scope. We realized that this approach (Table 2) was inefficient with $\mathrm{Z}-\mathrm{Cl}$ or the highly reactive dibenzyldicarbonate $\left(\mathrm{Z}_{2} \mathrm{O}\right)$, leading to their fast decomposition into benzyl alcohol and very poor conversions (less than $10 \%$ ), with most of the starting unreacted amino acid. Benzyloxysuccinimide (ZOSu) was suitable for carbamate bond formation under cycled milling, leading to various $\mathrm{Z}-\mathrm{N}$-protected amino acids as pure compounds after simple precipitation/filtration workup in acidic medium (Table 2).

Byproducts like inorganic salts or hydroxysuccinimide were soluble in water and easily washed from the crude. In some cases (Supporting Information), $\mathrm{Et}_{2} \mathrm{O}, \mathrm{CHCl}_{3}$, or AcOEt extraction was necessary. $\gamma$ - $N$-Benzyloxycarbonyl-lysine was also prepared, but it was necessary to adjust the milling conditions for the second step.

$D$-Lysine-OH led to traces of $\mathrm{Z}-\alpha$-aminobenzyl ester when more energetic conditions were used ( 36 balls at 500 or 650 rpm under continuous milling). Indeed, when the crude was grinded using cycled milling for $3 \mathrm{~h}$ at $500 \mathrm{rpm}$ (entry 9, Table 2) with $10 \mathrm{~min}$ interruptions every $10 \mathrm{~min}$, the reaction was energetic enough to favor amine protection in good yield without concomitant ester formation (Table 2, entry 9). We were pleased to find that the reaction was suitable also for the synthesis of the $\beta$-amino acid $\mathrm{H}-\mathrm{D}, \mathrm{L}-3-\mathrm{Aib}-\mathrm{OH}$ (entry 12, Table 2).

9-Fluorenyloxycarbonyl N-Protected Amino Acids. Fmoc amino acids are commonly used for solid-phase peptide synthesis, ${ }^{31}$ especially with acido-labile side-chain protecting groups. They are prepared by slowly adding a solution of the amino acid in dilute sodium carbonate to a cold solution of Fmoc-Cl in dioxane, ether, or other solvent. ${ }^{20}$ This order of reagent addition avoided the presence of an excess of an amino function, which might lead to premature degradation of the desired Fmoc derivative. However, with the usual synthesis, some impurities such as dibenzofulvene or its polymer can be formed, using appropriate workup conditions to recover the pure product. During our ongoing study, the synthesis of Fmoc-protected amines was reported under solvent-free conditions using Fmoc-OSu/DMAP, with an excess of starting amine under vibration milling conditions. ${ }^{27}$

The methodology applied so far for the introduction of Bocand Z-protecting groups was extended to the synthesis of Fmoc amino acid derivatives (Table 3), and a variation of energy requirements was explored using different planetary milling apparatus and jar materials (stainless steel or tungsten carbide) (Table 4).

Despite the advantages coming from the use of $\mathrm{Fmoc}-\mathrm{Cl}$ (e.g., formation of inorganic salts soluble in water and easy to remove), this reagent was not suitable for the protection of $\alpha$ - 
Table 3. Fmoc $N$-Protected Amino Acids ${ }^{a}$ and Milling Conditions with Different Apparatus/Jar Material Combinations

\begin{tabular}{|c|c|c|c|c|}
\hline entry & apparatus $-\mathrm{rpm}-$ jar & $N^{b}$ & product & $\begin{array}{l}\text { yield } \\
(\%)^{c, d}\end{array}$ \\
\hline 1 & $\begin{array}{l}\text { PM1 - } 650 \text { - stainless } \\
\text { steel }\end{array}$ & 24 & Fmoc-Phe-OH & $87^{e}$ \\
\hline 2 & $\begin{array}{l}\text { PM1 - } 500-\text { stainless } \\
\text { steel }\end{array}$ & 36 & $\begin{array}{l}\text { Fmoc-Tyr }(\mathrm{Me})- \\
\mathrm{OH}\end{array}$ & $95^{e}$ \\
\hline 3 & $\begin{array}{l}\text { PM1 - } 500 \text { - stainless } \\
\text { steel }\end{array}$ & 36 & $\begin{array}{l}\text { Fmoc-Ser(Bzl)- } \\
\quad \mathrm{OH}\end{array}$ & $76^{e}$ \\
\hline 4 & PM1 - 500 - WC jar & 50 & $\begin{array}{l}\text { Fmoc-His(Trt)- } \\
\text { OH }\end{array}$ & $34^{f}$ \\
\hline 5 & PM2 - $650-$ & 50 & & $63^{f}$ \\
\hline 6 & PM1 - 500 - WC jar & 80 & $\begin{array}{l}\text { Fmoc-Thr(Bzl)- } \\
\text { OH }\end{array}$ & $48^{e}$ \\
\hline 7 & PM2 - 750 & 50 & & $64^{g}$ \\
\hline 8 & PM1 - $500-$ WC jar & 50 & Fmoc-Leu-OH & $25^{e}$ \\
\hline 9 & PM2 - 750 & 50 & & $55^{g}$ \\
\hline
\end{tabular}

${ }^{a}$ Configuration of all substrates is $L .{ }^{b}$ Number of balls. ${ }^{c}$ Method: 12 $\mathrm{mL}$ stainless steel jar or $50 \mathrm{~mL}$ tungsten carbide (WC) jar in a planetary ball mill: (step 1) $\alpha$-amino acid (1.0 equiv), $\mathrm{K}_{2} \mathrm{CO}_{3}(1.0$ equiv), $\mathrm{NaCl}$ (quantity in grams corresponding to the total weight of the reactants), balls (0.5 mm diameter) ar $500 \mathrm{rpm}$ for $2 \mathrm{~h}$; (step 2) Fmoc-OSu (1.0 equiv) and $\mathrm{NaCl}$ (quantity in grams corresponding to the total weight of $\mathrm{Fmoc}-\mathrm{OSu}$ introduced). ${ }^{d}$ Isolated yield after workup. ${ }^{e}$ Continuous milling for $2 \mathrm{~h}$ (step 2). ${ }^{f}$ Continuous milling for $3 \mathrm{~h}$ (step 2). ${ }^{g}$ Twelve cycled milling of $10 \mathrm{~min}$ cycles followed by 5 min of standby in between with reverse rotation.

Table 4. Overview of Planetary Ball-Milling Apparatus and Grinding Jars for Fmoc-Protection of Amino Acid

\section{Derivatives}

$\begin{array}{clclc}\text { entry } & \text { apparatus (abbreviation) } & \begin{array}{c}V_{\text {jar }} \\ (\mathrm{mL})\end{array} & \begin{array}{c}n \text { of balls }(0.5 \\ \mathrm{mm} \varnothing)\end{array} & \text { material } \\ 1 & \text { PM 100 (PM1) } & 12 & 12,24,36,50 & \text { steel } \\ 2 & \text { PM 100 (PM1) } & 50 & 50,80 & \text { WC } \\ 3 & \begin{array}{c}\text { pulverisette 7 premium line } \\ \text { (PM2) }\end{array} & 20 & 50 & \text { steel }\end{array}$

amino acids due to decomposing very fast to dibenzofulvene in the planetary ball mill. In the case of Fmoc-Phe-OH (entry 1, Table 3), by keeping constant the milling rotation at $500 \mathrm{rpm}$ while increasing the number of milling balls $(6,12$ or 24), yields were improved ( $45 \%$ with 6 balls to $70 \%$ with 24 balls) but still some traces of dibenzofulvene were present in the crude. In this case, more energetic conditions are achieved by increasing the rotation speed to $650 \mathrm{rpm}$, which led to a better yield $(85 \%$, entry 1, Table 3) of Fmoc-Phe-OH without dibenzofulvene formation. In this case also, the workup was really practical because the protonated water-insoluble Fmoc-Phe-OH precipitated after treatment with $10 \%$ aqueous citric acid, while water-soluble $\mathrm{N}$-hydroxysuccinimide was washed out during filtration. Similarly, Fmoc-Tyr $(\mathrm{Me})-\mathrm{OH}$ and FmocSer(Bzl)-OH (entries 2 and 3, Table 3) were easily recovered as white powders in good to excellent yields after the usual workup.

In general, the use of Fmoc-OSu in solution can lead, together with dibenzofulvene, to in situ formation of side products (i.e., Fmoc- $\beta$-Ala- $\mathrm{OH}$ or dipeptides Fmoc- $\beta$-Ala$\mathrm{AA}-\mathrm{OH}$ via the Lossen rearrangement). ${ }^{32,33}$ In our case, dibenzofulvene was detected in a low amount as the only byproduct under unoptimized conditions (prolonged and moderate energetic milling), while no traces of byproduct
Fmoc- $\beta$-Ala-OH could be detected by mass spectrometry analyses of the crude.

Actually, we extended the study to other amino acids, speculating that the more energetic conditions applied into the grinding jar the higher the yields should be. First, this was accomplished by increasing the number of balls, rotation speed, and extending the reaction times under continuous or cycled mode. Then, stainless steel grinding jars and balls were replaced by tungsten carbide (WC). For each amino acid investigated, Table 3 (entries 4-9) summarizes the best data obtained in the optimized apparatus/grinding material/rotation speed/number of balls combinations. Despite the moderate yields, from the data shown, it seemed that rotation speed influenced yield (doubled!!!) and selectivity more than the choice of a lighterweight (steel; PM2) or heavier milling material (tungsten carbide; PM1), while extended reaction time could be sometimes detrimental leading to side products. Typically, Fmoc-Pro-OH could be obtained (23\% yield) at $750 \mathrm{rpm}$ (PM2; stainless steel jar; 50 balls) after 2 h (cycles milling), while it was not formed using at lower rotation speed of 500 rpm (PM1; tungsten carbide jar; 50 balls rpm) during $3 \mathrm{~h}$ of continuous milling. A question remaining open and with no answer at the moment for technical reasons concerns the outcome of syntheses using a tungsten carbide jar (WC jar) in the PM2 conditions at higher rotation speed.

\section{CONCLUSIONS}

We have developed a new and advantageous synthetic procedure with low environmental impact for preparing $\mathrm{N}$ protected amino acids under mild conditions without special precaution, which is easy to realize, keeping the quantity of solvent used for the workup to the minimum and with no need of tedious purification steps. The "greenness" of a method is evaluated considering its environmental factor ${ }^{34}[E$-factor $=$ total waste $(\mathrm{kg}) /$ product $(\mathrm{kg})]$, defined by the ratio of mass of waste per unit of product. The protection of $L-\mathrm{Phe}-\mathrm{OH}$ with Boc, Z, and Fmoc groups was used as benchmark to compare the $E$-factors for both solution and solvent-free syntheses (Table 5).

Table 5. Comparative E-Factors for N-Protection of Amino Acids

\begin{tabular}{cccc} 
& & \multicolumn{2}{c}{$E$-factor } \\
\cline { 3 - 4 } entry & $N$-protected amino acid & solution synthesis & solvent-free synthesis \\
1 & Boc-Phe-OH & 62 & 265 \\
2 & Z-Phe-OH & 20 & 8 \\
3 & Fmoc-Phe-OH & 288 & 6 \\
\hline
\end{tabular}

In the majority of cases, the E-factor is much better compared to the reactions carried out in solvents, especially for Z- and Fmoc-protection, displaying a comparatively lower environmental. For Boc-protection, if the nature of waste is the same for both methods (in solution or solvent free), the need for liquid-liquid extraction workup is detrimental from environmental point of view.

Amino acid derivatives were synthesized in a scale from 50 $\mathrm{mg}$ up to $1 \mathrm{~g}$ of final product. The final pure protected amino acid derivatives were recovered by aqueous precipitation/ filtration or liquid-liquid extraction. Different apparatus were used, and an investigation of the parameters responsible for energy efficiency was presented. Work is in progress to extend 
the methodology to more complex protecting groups for amino acids and esters of biological interest and to investigate more deeply the Fmoc-protection from a process point of view.

\section{EXPERIMENTAL SECTION}

Representative Procedure for the Synthesis of $\mathbf{N}$-BocProtected Amino Acids. The amino acid (1 equiv), $\mathrm{K}_{2} \mathrm{CO}_{3}$ (1 equiv), and $\mathrm{NaCl}$ (quantity in grams corresponding to the total weight of the reactants) were introduced in a $12 \mathrm{~mL}$ stainless grinding jar with 24 stainless balls ( $5 \mathrm{~mm}$ diameter). The reaction medium was ground at $500 \mathrm{rpm}$ for $2 \mathrm{~h}$. Then, $\mathrm{Boc}_{2} \mathrm{O}$ ( 1 equiv) and $\mathrm{NaCl}$ (quantity in grams corresponding to the total weight of $\mathrm{Boc}_{2} \mathrm{O}$ ) were added to the reaction medium, and the latter was ground at $300 \mathrm{rpm}$ for $3 \mathrm{~h}$ (three cycles of $1 \mathrm{~h}$, intervals of $10 \mathrm{~min}$ between each cycle, with inverse rotation). $\mathrm{Et}_{2} \mathrm{O}$ and water were then added to the crude. The aqueous layer was then acidified with citric acid $10 \%$ aq and extracted with $\mathrm{CHCl}_{3}$. The organic layer was dried over $\mathrm{MgSO}_{4}$, filtered, and concentrated under reduced pressure to give the product as a powder after drying on $\mathrm{KOH}$ under vacuum.

Representative Procedure for the Synthesis of Z- or FmocProtected $\boldsymbol{\alpha}$-Amino Acids. The amino acid (1 equiv), $\mathrm{K}_{2} \mathrm{CO}_{3}$ (1 equiv), and $\mathrm{NaCl}$ (quantity in grams corresponding to the total weight of the reactants) were introduced in a $12 \mathrm{~mL}$ stainless grinding jar with 24 stainless balls ( $5 \mathrm{~mm}$ diameter). The reactants were ground at 500 $\mathrm{rpm}$ for $2 \mathrm{~h}$. Then, the suitable protecting group (Z-OSu or Fmoc$\mathrm{OSu}, 1$ equiv) and $\mathrm{NaCl}$ (quantity in grams corresponding to the total weight of the protecting group precursor used) were added to the reaction medium, and the latter was ground at $500 \mathrm{rpm}$ for $2 \mathrm{~h}$. $\mathrm{HCl} 1$ $\mathrm{N}$ was added to the crude (or citric acid $10 \%$ aq), leading to the precipitation of the product. The latter was filtered and washed with water until neutral $\mathrm{pH}$, to afford the title compound as a white powder after drying over $\mathrm{P}_{2} \mathrm{O}_{5}$.

\section{AUTHOR INFORMATION}

\section{Corresponding Author}

*E-mail: evelina.colacino@univ-montp2.fr.

\section{Notes}

The authors declare no competing financial interest.

\section{ACKNOWLEDGMENTS}

We acknowledge Mr. Julien Fullenwarth (Institut Charles Gerhardt, Montpellier) for giving us access to the Planetary Mill Pulverisette 7 Premium (Fritsch) for some experiments.

\section{REFERENCES}

(1) Anastas, P. T.; Warner, J. C. Green Chemistry: Theory and Practice; Oxford University Press: Oxford U.K., 1998.

(2) Handbook of Green Chemistry and Technology; Lancaster, M., Ed.; Blackwell Publishing: Abingdon, 2002.

(3) Anastas, P.; Heine, L. G.; Williamson, T. C. Green Chemical Syntheses and Processes; Oxford University Press: New York, 2000.

(4) Baird, C. Environmental Chemistry; W.H. Freeman: New York, 1999.

(5) Matlack, A. S. Introduction to Green Chemistry; Marcel Dekker: New York, 2001.

(6) Green Chemistry: Frontiers in Benign Chemical Syntheses and Processes; Anastas, P. T., Williamson, T. C., Eds.; Oxford University Press: New York, 1999.

(7) Tanaka, K.; Toda, F. Solvent-free organic synthesis. Chem. Rev. 2000, 100, 1025-1074.
(8) Toda, F. Organic solid state reactions. Top. Curr. Chem. 2005, $254,1-305$.

(9) Stolle, A.; Szuppa, E.; Leonhardt, S. E. S.; Ondruschka, B. Ball milling in organic synthesis: Solutions and challenges. Chem. Soc. Rev. 2011, 40, 2317-2329.

(10) Martins, M. A. P.; Frizzo, C. P.; Moreira, D. N.; Buriol, L.; Machado, P. Solvent-free heterocyclic synthesis. Chem. Rev. 2009, 109, 4140-4182.

(11) Sheldon, R. A. Atom efficiency and catalysis in organic synthesis. Pure Appl. Chem. 2000, 72, 1233-1246.

(12) Métro, T. X.; Bonnamour, J.; Reidon, T.; Sarpoulet, J.; Martinez, J.; Lamaty, F. Mechanosynthesis of amides in the total absence of organic solvent from reaction to product recovery. Chem. Commun. 2012, 48, 11781-11783.

(13) Declerck, V.; Nun, P.; Martinez, J.; Lamaty, F. Solvent-free synthesis of peptides. Angew. Chem., Int. Ed. 2009, 48, 9318-9321.

(14) Martinez, J.; Lamaty, F.; Declerck, V. Method for Solvent-Free Peptide Synthesis. Patent WO 2008125418, 2008.

(15) Baron, A.; Martinez, J.; Lamaty, F. Solvent-free synthesis of unsaturated amino esters in a ball-mill. Tetrahedron Lett. 2010, 51, $6246-6249$.

(16) Nun, P.; Pérez, V.; Calmès, M.; Martinez, J.; Lamaty, F. Preparation of chiral amino esters by asymmetric phase-transfer catalyzed alkylations of Schiff bases in a ball mill. Chem.-Eur. J. 2012, $18,3773-3779$.

(17) Synthesis of Peptides and Peptidomimetics, Vol. E22; Goodman, M., Felix, A., Moroder, L., Toniolo, C., Eds.; Thieme: Stuttgart, 2002.

(18) Wuts, P. G. M.; Greene, T. W. Greene's Protective Groups in Organic Synthesis, Fourth ed.; John Wiley \& Sons: New York, 2006.

(19) Isidro-Llobet, A.; Alvarez, M.; Albericio, F. Amino acidprotecting groups. Chem. Rev. 2009, 109, 2455-2504.

(20) Carpino, L. A.; Grace, Y. H. The 9-fluorenylmethoxycarbonyl amino-protecting group. J. Org. Chem. 1972, 37, 3404-3409.

(21) Anderson, G. W.; McGregor, A. C. t-Butyloxycarbonylamino acids and their use in peptide synthesis. J. Am. Chem. Soc. 1957, 79, $6180-6183$

(22) Tarbell, D. S.; Yamamoto, Y.; Pope, B. M. New method to prepare $\mathrm{N}$-t-butoxycarbonyl derivatives and the corresponding sulfur analogs from di-t-butyl bicarbonate or di-t-butyl dithiol dicarbonates and amino acids. Proc. Natl. Acad. Sci. U.S.A. 1972, 69, 730-732.

(23) Bergmann, M.; Zervas, L. Über ein allgemeines Verfahren der Peptid-Synthese. Ber. Deut. Chem. Ges. 1932, 65B, 1192-1201.

(24) Giri, N.; Bowen, C.; Vyle, J. S.; James, S. L. Fast, quantitative nucleoside protection under solvent-free conditions. Green Chem. 2008, 10, 627-628.

(25) Patil, P. R.; Kartha, K. P. R. Application of ball milling technology to carbohydrate reactions: I. Regioselective primary hydroxyl protection of hexosides and nucleoside by planetary ball milling. J. Carbohydr. Chem. 2008, 27, 279-293.

(26) Sikchi, S. A.; Hultin, P. G. Solventless protocol for efficient Bis$\mathrm{N}$-Boc protection of adenosine, cytidine, and guanosine derivatives. J. Org. Chem. 2006, 71, 5888-5891.

(27) Ravalico, F.; James, S. L.; Vyle, J. S. Synthesis of nucleoside analogues in a ball mill: Fast, chemoselective and high yielding acylation without undesirable solvents. Green Chem. 2011, 13, 17781783.

(28) Kaupp, G.; Naimi-Jamal, M. R.; Stepanenko, V. Waste-free and facile solid-state protection of diamines, anthranilic acid, diols, and polyols with phenylboronic acid. Chem.-Eur. J. 2003, 9, 4156-4160.

(29) Schneider, F.; Stolle, A.; Ondruschka, B.; Hopf, H. The SuzukiMiyaura reaction under mechanochemical conditions. Org. Proc. Res. Dev. 2009, 13, 44-48.

(30) Verma, S. K.; Ghorpade, R.; Pratap, A.; Kaushik, M. P. Solvent free, $\mathrm{N}, \mathrm{N}^{\prime}$-carbonyldiimidazole (CDI) mediated amidation. Tetrahedron Lett. 2012, 53, 2373-2376.

(31) Fields, G.; Noble, R. L. Solid phase peptide synthesis utilizing 9fluorenylmethoxycarbonyl amino acids. Int. J. Pept. Prot. Res. 1990, 35, $161-214$. 
(32) Hlebowicz, E.; Andersen, A. J.; Andersson, L.; Moss, B. A. Identification of Fmoc-beta-Ala-OH and Fmoc-beta-Ala-amino acid$\mathrm{OH}$ as new impurities in Fmoc-protected amino acid derivatives. $J$. Pept. Res. 2005, 65, 90-97.

(33) Isidro-Llobet, A.; Just-Baringo, X.; Ewenson, A.; Alvarez, M.; Albericio, F. Fmoc-2-mercaptobenzothiazole, for the introduction of the Fmoc moiety free of side-reactions. Biopolymers 2007, 88, 733737.

(34) Sheldon, R.; Arends, A. I. and Hanefeld, U. Green Chemistry and Catalysis; Wiley-VCH, Weinheim, Germany, 2007. 